\author{
KRZYSZTOF KUŁAK \\ ORCID: 0000-0001-6785-2468
}

Uniwersytet Wrocławski

\title{
AUTONOMIA KODEKSU SPÓŁEK HANDLOWYCH - MIĘDZY MONIZMEM A DUALIZMEM PRAWA PRYWATNEGO
}

\begin{abstract}
Abstrakt: Przedmiotem opracowania jest problematyka jedności prawa prywatnego i idei powrotu do koncepcji dualistycznej. Punktem wyjścia prowadzonych rozważań jest regulacja kodeksu spółek handlowych, która mimo normatywnie usankcjonowanego ujęcia monistycznego zachowuje daleko idącą autonomię względem tradycyjnie rozumianego prawa cywilnego, zachęcając do dyskusji nad powrotem do dwutorowego uregulowania stosunków prywatnoprawnych. Już zresztą kształt zawartego w kodeksie cywilnym unormowania obrotu gospodarczego skłania do wniosku, że mamy do czynienia $\mathrm{z}$ dualizmem regulacyjnym, o jedności zaś można zasadnie mówić tylko w kontekście jedności kodyfikacyjnej. Okoliczność ta wraz z postępującą specjalizacją obrotu handlowego i sprzyjającymi uwarunkowaniami społeczno-ekonomicznymi skłaniają do przeglądu, uporządkowania i uzupełnienia normatywnej regulacji tej sfery obrotu czy to w ramach kodeksu cywilnego, czy to w osobnym kodeksie handlowym.
\end{abstract}

Słowa kluczowe: prawo handlowe, prawo cywilne, prawo prywatne, prawo spółek, monizm prawa prywatnego, dualizm prawa prywatnego, jedność prawa prywatnego, kodeks spółek handlowych, kodeks cywilny, autonomia prawa spółek

I. Quieta non movere et mota quietare 1 . Myśl ta może być mottem prawniczego tradycjonalizmu i wstrzemięźliwości, odwodząc od wszelkich rewolucyjnych zmian w zastanym porządku. Niech jednak właśnie ona - nieco przewrotnie daje asumpt do spojrzenia, z perspektywy prawa spółek, na ideę powrotu do koncepcji dualizmu polskiego prawa prywatnego ${ }^{2}$.

1 Łac. „nie ruszać tego, co spokojne, wyciszyć to, co wzburzone”.

2 Mówienie o jedności (dualizmie) prawa prywatnego wydaje się właściwsze od posługiwania się określeniem ,jedność (dualizm) prawa cywilnego". Pojęcia zarówno monizmu, jak i dualizmu ze swej istoty zakładają bowiem istnienie więcej niż jednej kategorii podlegającej określonemu łączeniu lub rozdziałowi. Obciążone błędem logicznym byłoby zwłaszcza mówienie o „dualizmie prawa cywilnego", skoro pojęcie to ma oznaczać właśnie odrębność prawa cywilnego (powszechnego) i prawa handlowego. $Z$ tego względu opracowanie odwołuje się w tym kontekście do nadrzędnej 
Dwadzieścia lat mijających od uchwalenia kodeksu spółek handlowych ${ }^{3}$ to okres sprzyjający ocenie tej regulacji i pozwalający na weryfikację słuszności założeń przyświecających jej twórcom, którzy zdecydowali się utrzymać zadekretowaną wraz $\mathrm{z}$ wejściem w życie kodeksu cywilnego ${ }^{4}$ zasadę jedności prawa prywatnego. $Z$ dzisiejszej perspektywy można jednak odnieść wrażenie, że tocząca się od końca lat osiemdziesiątych XX wieku dyskusja dotycząca wyboru między kontynuacją monizmu a powrotem do dualizmu prawa prywatnego została nieco apriorycznie ukierunkowana na koncepcję monistyczną wewnętrznymi decyzjami Komisji ds. Reformy Prawa Cywilnego, Grupy Roboczej ds. Reformy Prawa Spółek, a ostatecznie Komisji Kodyfikacyjnej Prawa Cywilnego ${ }^{5}$, a następnie, zdominowana głosem klasycznej cywilistyki, zakończyła się, zanim na dobre rozgorzała ${ }^{6}$, ogniskując się ostatecznie na zagadnieniach dotyczących rozwiązań szczegółowych. I choć ostatecznie kodeks spółek handlowych został wpasowany, po myśli art. 1 k.c., w ramy prawa cywilnego, specyfika stosunków powstających na gruncie prawa spółek (silny pierwiastek organizacyjny związany z kreacją odrębnego podmiotu prawa wchodzącego $\mathrm{w}$ stosunki prawne $\mathrm{z}$ osobami trzecimi

kategorii prawa prywatnego, obejmującej zarówno prawo cywilne, jak i prawo handlowe. Zob. też S. Włodyka, O sposobach normatywnej regulacji prawa handlowego, PiP 1999, nr 9, passim; oraz M. Pazdan, Kodeks spótek handlowych a kodeks cywilny, PiP 2001, nr 2, s. 28; A. Całus, Miejsce instytucji prawa handlowego $w$ procesie komercjalizacji prawa cywilnego. Uwagi w zwiazku z pracami nad nowym kodeksem cywilnym, [w:] Instytucje prawa handlowego w przyszłym kodeksie cywilnym, red. T. Mróz, M. Stec, Warszawa 2012, s. 29.

${ }^{3}$ Ustawa z dnia 15 września 2000 roku — Kodeks spółek handlowych, Dz.U. z 2019 r. poz. 505 (dalej: kodeks lub k.s.h.).

${ }^{4}$ Ustawa z dnia 23 kwietnia 1964 roku — Kodeks cywilny, Dz.U. z 2019 r. poz. 1145 (dalej: k.c.).

5 Zob. więcej S. Sołtysiński, Spóźniona reforma prawa spótek handlowych, PPH 1999, nr 5, s. 2.

6 Zob. A. Całus, Problematyka handlowa w reformie kodeksu cywilnego (I), „Przegląd Ustawodawstwa Gospodarczego" 1990, nr 8-9, s. 124, który już w 1990 roku wzmiankuje uchwałę Komisji ds. Reformy Prawa Cywilnego, opowiadającą się za „utrzymaniem zasady jedności prawa cywilnego i ostatecznym odejściem, co najmniej w kodyfikacji, od podziału prawa prywatnego na kodeks cywilny i kodeks handlowy", oraz Z. Radwański, Koncepcja kodyfikacji prawa cywilnego, [w:] Księga pamiątkowa. I Kongres Notariuszy Rzeczypospolitej Polskiej, red. A. Oleszko, R. Sztyk, PoznańKluczbork 1993, s. 197-212; M. Paluch, Kierunki reformy prawa spółek handlowych, MoP 1998, nr 8, s. 296 n.; oraz J. Jacyszyn, Projekt ustawy - Prawo spółek handlowych (ogólna charakterystyka), „Rejent” 1999, nr 1, s. 27-31; S. Sołtysiński, Kodeks spótek handlowych. (Podstawowe zatożenia), PiP 2000, nr 11, s. 5-6; idem, Przepisy ogólne kodeksu spótek handlowych. (Wybrane zagadnienia), PiP 2001, nr 7, s. 4. Por. jednak J. Skąpski, O stanie i potrzebach prawa cywilnego - uwag kilka, „Przegląd Sądowy” 1992, nr 7-8, s. 8 n.; idem, Kodeks cywilny z 1964 r. Blaski i cienie kodyfikacji oraz jej perspektywy, KPP 1992, nr 1-4, s. 86 n.; J. Frąckowiak, O konieczności dalszych zmian prawa cywilnego szczególnie w odniesieniu do podmiotów i umów w obrocie gospodarczym, PPH 1999, $\mathrm{nr} 3$, s. 7; idem, Ustawodawstwo dotyczace przedsiębiorców pod rządami zasady jedności prawa cywilnego, PPH 2000, nr 11; idem, Instytucje prawa handlowego w kodeksie cywilnym, „Rejent” 2003, $\mathrm{nr} 6$, s. 16, który uznaje, że pozostanie przy jedności prawa prywatnego wywołało wiele negatywnych następstw skutkujących niedostatkami regulacji obrotu handlowego. Jest to tym bardziej interesujące, że w dyskusji nie była dostatecznie eksponowana rzeczywista przyczyna formalnego wprowadzenia w 1964 roku zasady jedności prawa prywatnego, o której piszą J. Okolski, W. Opalski, Znaczenie prawa handlowego w świetle koncepcji jedności prawa cywilnego, PPH 1992, nr 1, s. 2-3.

Przegląd Prawa i Administracji CXXI, 2020

(C) for this edition by CNS 
przy jednoczesnym braku typowo obligacyjnego charakteru ${ }^{7}$ ) musiała odcisnąć na nim swoje piętno, na płaszczyźnie normatywnej wymuszając stworzenie swoistego zaworu bezpieczeństwa w postaci art. 2 k.s.h. i skutkując wyłączeniem regulacji kodeksu spółek handlowych przed nawias kodeksu cywilnego.

Celem niniejszych rozważań nie jest szczegółowe wskazywanie argumentów przemawiających za powrotem do dualistycznego rozdziału na prawo cywilne i prawo handlowe, gdyż analiza taka wykraczałaby poza ramy tego opracowania. Chodzi tu raczej o zaprezentowanie ogólnej refleksji płynącej ze spojrzenia na zagadnienie jedno- lub dwutorowości prawa prywatnego z perspektywy kodeksu spółek handlowych jako jego specyficznej dziedziny, która wbrew pierwotnym zamierzeniom i normatywnym deklaracjom zdaje się wymykać monistycznemu ujmowaniu tej gałęzi prawa. Kodeks ten może być jednocześnie przykładem tego, że niekonsekwencja prawodawcy i brak wyraźnego rozgraniczenia reżimu prawa handlowego i cywilnego mogą skutkować niepotrzebnymi wątpliwościami i trudnościami w praktycznym stosowaniu norm tego pierwszego.

II. Na tle rozważań dotyczących wyboru między monistycznym i dualistycznym ujęciem prawa prywatnego kodeks spółek handlowych jest regulacją o szczególnym charakterze. Nie ulega wątpliwości, że zakodowane w jego przepisach normy ustrojowe istotnej kategorii przedsiębiorców, jakimi są spółki handlowe, adresowane przede wszystkim do nich samych, są normami prawa handlowego ${ }^{8}$. Zarówno więc pod względem przedmiotu regulacji, jak i w wymiarze podmiotowym kodeks jako lex specialis względem kodeksu cywilnego ${ }^{9}$ pozostaje na uboczu głównego nurtu prawa cywilnego i to mimo funkcjonowania w warunkach jedności prawa prywatnego. W minimalnym jedynie stopniu można to wiązać z jego formalną samodzielnością jako ustawy pozakodeksowej, której - co warto podkreślić - mimo głosów sprzeciwu ze strony klasycznej cywilistyki ${ }^{10}$

7 S. Sołtysiński, [w:] S. Sołtysiński, A. Szajkowski, J. Szwaja, Kodeks handlowy. Komentarz, t. 1, Warszawa 1994, s. 18; idem, Przepisy ogólne kodeksu..., s. 5; A. Kidyba, Komentarz aktualizowany do art. 1-300 Kodeksu spótek handlowych, LEX 2020, art. 2 uw. 2 i 3.

${ }^{8}$ Prawo handlowe jest tu rozumiane jako ogół norm prywatnoprawnych regulujących ustrój, funkcjonowanie i ustanie bytu prawnego przedsiębiorców oraz powstające w toku obrotu handlowego stosunki prawne z ich udziałem (K. Kruczalak, Prawo handlowe. Zarys wyktadu, Warszawa 1997, s. 21).

${ }^{9}$ Zob. uzasadnienie projektu ustawy - Kodeks spółek handlowych (druk sejmowy nr 1687), pkt I 4 i II 1 (iv); J. Szwaja, Nowy kodeks spółek handlowych, cz. 1-2, „Prawo Spółek” 2001, nr 1, s. 5-6; Kodeks spółek handlowych. Komentarz, red. J. Strzępka, E. Zielińska, Warszawa 2015, art. 2 uw. 1; P. Nazaruk, [w:] Kodeks cywilny. Komentarz, red. J. Ciszewski, P. Nazaruk, Warszawa 2019, art. 1 uw. 15 .

10 Zob. S. Sołtysiński, Kodeks spótek handlowych..., s. 5-6; J. Brol et al., Kodeks spółek handlowych. Komentarz, Warszawa 2001, art. 2 uw. 2 i 4. Zob. też R. Siwik, [w:] Kodeks spótek handlowych. Komentarz, red. Z. Jara, Warszawa 2020, art. 2 uw. nb. 5 i 19, który wskazuje, że autonomia ta dotyczy treści rozwiązań przyjętych w kodeksie (względem rozwiązań kodeksu cywilnego) oraz wykładni przepisów kodeksu. 
nadano ostatecznie rangę kodeksową (choć jest to skutek, a nie przyczyna owej specyfiki $\left.{ }^{11}\right)$.

Kluczowa okazuje się tu autonomia prawa spółek, nawet jeśli ma ona — jak się powszechnie przyjmuje - charakter tylko ograniczony ${ }^{12}$. Znajduje on normatywny wyraz w art. 2 k.s.h. Przepis ten pozostaje jednak wtórny względem materii kodeksu, która nie jest przecież zawieszona w próżni, ale w zakresie siatki pojęciowej $\mathrm{i}$ instytucji ogólnych, w braku własnych rozwiązań, musi odwoływać się do ogólnych przepisów kodeksu cywilnego. W piśmiennictwie wskazano zresztą na ograniczoną rolę czy wręcz brak normatywnego znaczenia art. 2 k.s.h. jako przepisu będącego jedynie kontynuacją i rozwinięciem zasady z art. 1 k.c. ${ }^{13}$, uznając go w konsekwencji za superfluum ustawowe ${ }^{14}$. W nieco innym ujęciu przyjęto, że funkcją tego przepisu jest ograniczenie zasady jedności prawa prywatnego na gruncie kodeksu spółek handlowych ${ }^{15}$. Przepis ten ma przede wszystkim walor porządkujący, pełniąc funkcję podobną do dyrektyw wykładni drugiego stopnia i jednocześnie stanowiąc formalne zakotwiczenie kodeksu spółek handlowych w prawie cywilnym. Co jednak warto podkreślić, ograniczone znaczenie art. 2 k.s.h. nie oznacza ograniczonego znaczenia autonomii kodeksu. Przeciwnie, zdecydowana większość jego regulacji nie wymaga odwoływania się do przepisów kodeksu cywilnego, których stosowanie do spraw uregulowanych w prawie spółek jest — jak ujął to W. Pyzioł — „potencjalnie aktualne raczej tylko w rzadkich przypadkach"16.

W warstwie czysto normatywnej art. 2 k.s.h. jest regulacją klarowną, która sama w sobie nie powinna być źródłem wątpliwości. W zdaniu pierwszym przepis ten przewiduje stosowanie wprost do stosunków prawnospółkowych przepisów kodeksu cywilnego po wyczerpaniu regulacji kodeksu spółek handlowych (i po ustaleniu, że nie zachodzi przypadek tak zwanej regulacji negatywnej ${ }^{17}$ ). W zdaniu

11 Zob. uzasadnienie projektu ustawy — Kodeks spółek handlowych, pkt I 2 (vii).

12 Zob. S. Sołtysiński, Przepisy ogólne kodeksu..., s. 5; A. Szajkowski, [w:] System Prawa Prywatnego, t. 16. Prawo spółek osobowych, red. A. Szajkowski, Warszawa 2016, s. 12; A. Kidyba, Komentarz aktualizowany..., art. 2 uw. 2; M. Spyra, [w:] J. Bieniak et al., Kodeks spótek handlowych. Komentarz, Warszawa 2020, art. 2 uw. 2, który uważa, że nie chodzi tu o autonomię względem tylko kodeksu cywilnego, ale w ogóle prawa prywatnego. Zob. też uzasadnienie projektu ustawy Kodeks spółek handlowych, pkt II 1 (iv), w którym mówi się o „bardzo ograniczonej” autonomii kodeksu.

13 Tak T. Siemiątkowski, R. Potrzeszcz, [w:] Kodeks spótek handlowych. Komentarz. Tytuł I. Przepisy ogólne. Tytuł II. Spótki osobowe, red. T. Siemiątkowski, R. Potrzeszcz, Warszawa 2011, art. 2 uw. 1. Podobnie M. Spyra, op. cit., art. 2 uw. 1. Zob. też uzasadnienie projektu ustawy — Kodeks spółek handlowych, pkt I 4, w którym wskazuje się, że przepis ten ma znaczenie „dydaktyczne”.

14 T. Siemiątkowski, R. Potrzeszcz, op. cit., art. 2 uw. 2 i 3. Zob. też S. Sołtysiński, Kodeks spótek handlowych..., s. 5, który wspomina obawy części uczestników dyskusji nad projektem kodeksu co do tego, czy omawiany przepis nie wyprowadzi kodeksu poza ramy prawa cywilnego.

15 Zob. M. Spyra, op. cit., art. 2 uw. 1.

16 W. Pyzioł, [w:] Kodeks spółek handlowych. Komentarz, red. W. Pyzioł, Warszawa 2008, art. 2 uw. 2.

17 Zob. bliżej M. Pazdan, op. cit., s. 33. 
zaś drugim, honorując specyfikę tych stosunków, nakazuje, aby w razie potrzeby sięganie po regulację kodeksu cywilnego odbywało się na zasadzie odpowiedniości jej stosowania. W tym sensie funkcjonowanie prawa spółek w modelu jedności prawa prywatnego jawi się jako nieskomplikowane. Stosowanie przepisów kodeksu cywilnego do stosunków powstających na gruncie prawa spółek co do zasady nie nastręcza trudności w odniesieniu do ogólnej regulacji zdolności prawnej i zdolności do czynności prawnych, formy czynności prawnych, biegu terminów, przedawnienia roszczeń, zasad odpowiedzialności itp. Tego rodzaju odwołania do kodeksu cywilnego, jako naturalna konsekwencja sposobu ukształtowania treści i zakresu kodeksu spółek handlowych, mają charakter niejako programowy, z góry założony przez prawodawcę.

Blisko dwadzieścia lat obowiązywania kodeksu dowiodło jednak, że stosowanie, a czasem sama tylko pokusa stosowania (choćby odpowiedniego) przepisów kodeksu cywilnego do specyficznej materii prawa handlowego może być też źródłem wątpliwości ${ }^{18}$. Przykładem jest tu problematyka zaskarżania i skutków zaskarżania uchwał właścicielskich organów spółek kapitałowych. Regulacja art. 252 i 425 k.s.h., mimo że w doktrynie prawa handlowego i orzecznictwie poglądy na jej materialnoprawny i samodzielny względem ogólnej sankcji nieważności z art. 58 k.c. charakter są już w zasadzie ugruntowane, wciąż bywa przedmiotem prób wpasowywania jej w ramy wyznaczone owym przepisem ${ }^{19}$. Podobnie można wskazać na zagadnienie wadliwości i uchylania się od skutków oświadczeń woli składających się na czynności prawne o skutkach korporacyjnych (organizacyjnych), na przykład oświadczenia o przystąpieniu do spółki i wniesieniu wkładów na pokrycie kapitału zakładowego ${ }^{20}$.

Trzeba też jednak przyznać, że możliwość posiłkowania się przepisami kodeksu cywilnego jest remedium na część problemów wynikających z niekompletności rozwiązań kodeksu spółek handlowych. Wskazać tu można na nieuregulowane w nim zagadnienie zaskarżania uchwał obieralnych organów spółek kapitałowych, zaskarżania uchwał wspólników spółek osobowych czy na problem tak zwanych uchwał nieistniejących, które wymykają się szczególnemu reżimowi z art. 249 i 252 oraz art. 422 i 425 k.s.h. Nie są to oczywiście gotowe i niebudzące wątpliwości rozwiązania, ale bez możliwości odwołania się do ogólnych przepisów

18 Zob. W. Pyzioł, op. cit., art. 2 uw. 2.

19 Zob. na przykład M. Wilejczyk, Stosowanie przepisów kodeksu cywilnego do wadliwych uchwat zgromadzeń wspólników spótek kapitałowych, PPH 2012, nr 4, s. 22; M. Rodzynkiewicz, Kodeks spótek handlowych. Komentarz, Warszawa 2018, art. 2 uw. 7. Zob. też M. Gutowski, Dopuszczalność stosowania art. 58 \$ 3 k.c. do podlegajacych uchyleniu uchwat zgromadzenia wspólników lub walnego zgromadzenia spółek kapitałowych, PPH 2009, nr 12, s. 19 n.; oraz K. Bilewska, M. Warzecha, Dopuszczalność stosowania art. 58 \& 3 k.c. do uchwat zgromadzeń spótek kapitatowych - polemika, PPH 2010, nr 7, s. 54 n.

20 Por. A. Kidyba, Komentarz aktualizowany..., art. 2 uw. 4 oraz przywołane tam orzecznictwo. T. Kurnicki, Stosowanie przepisów o wadach oświadczeń woli w prawie spółek (cz. I), „Prawo Spółek" 2006, nr 6, s. 26. 
kodeksu cywilnego wspomniane problemy byłyby zdecydowanie poważniejsze, a jeżeli w ogóle możliwe do rozstrzygnięcia na gruncie samego kodeksu spółek handlowych, to kosztem wątpliwych zabiegów interpretacyjnych.

Są wreszcie problemy, których rozwiązania próżno szukać w kodeksie spółek handlowych i uzupełniająco stosowanym kodeksie cywilnym. Zagadnieniem tego rodzaju jest problematyka tak zwanego organu kadłubowego, a w szczególności możliwości kwalifikowania go jako organu w ogóle, skuteczności podejmowanych przez niego czynności, zwłaszcza w kontekście rozróżnienia na czynności reprezentacji i prowadzenia spraw (nie rozstrzyga jej niedawna nowelizacja art. 39 k.c. ${ }^{21}$ ). Przykład ten dowodzi, że nawet uznanie prawa spółek za część prawa cywilnego nie gwarantuje zupełności regulacji normatywnej.

Podsumowując ten fragment rozważań, warto podkreślić, że autonomia prawa spółek nie jest wynikiem łaskawości prawodawcy, ale naturalną konsekwencją wspomnianej już specyfiki przedmiotu regulacji kodeksu spółek handlowych. Autonomia ta jest więc niejako ,genetycznie” i tym samym koniecznie związana ze specyfiką stosunków powstających w obszarze prawa spółek i jako taka nie podlega wartościowaniu ani ocenie jako rozwiązanie dobre albo złe.

III. Zasada monizmu prawa prywatnego nie oznacza jednolitej regulacji we wszystkich sferach obrotu prywatnoprawnego. Przeczyłoby to zresztą ex definitione sensowi wyróżniania obrotu powszechnego i handlowego ${ }^{22}$. Specyficzne pod względem podmiotowym i przedmiotowym normy prawa handlowego przeplatają się w kodeksie cywilnym z normami powszechnego prawa cywilnego ${ }^{23}$. Mówienie więc o jedności prawa prywatnego (a tym bardziej cywilnego) jest więc jedynie pewną konwencją, by nie powiedzieć fikcją. Aktualny stan zdecydowanie lepiej oddaje więc pojęcie jedności kodyfikacyjnej ${ }^{24}$. Niemniej nawet tak określona jedność nie ma charakteru absolutnego; widoczny wyłom w niej tworzy kodeks spółek handlowych obejmujący wyłącznie regulację prawnohandlową o wyraźnie zaznaczonej autonomii względem pozostałych norm prawa cywilnego. De facto mamy więc do czynienia ze swego rodzaju materialnym dualizmem regulacyjnym.

21 Zob. art. 1 ustawy z dnia 9 listopada 2018 roku o zmianie niektórych ustaw w celu wprowadzenia uproszczeń dla przedsiębiorców w prawie podatkowym i gospodarczym (Dz.U. z 2018 r. poz. 2244), który wszedł w życie 1 marca 2019 roku.

22 Zob. A. Kidyba, Prawo handlowe, Warszawa 2019, s. 4.

23 Por. A. Całus, Miejsce instytucji..., s. 29-30, który posługuje się pojęciem komercjalizacji prawa cywilnego na oznaczenie praktyki „wprowadzania do kodeksu [cywilnego — przyp. K.K.] instytucji obrotu lub prawa handlowego".

${ }^{24}$ Zob. M. Safjan, Z. Radwański, [w:] System Prawa Prywatnego, t. 1. Prawo cywilne - część ogólna, red. M. Safjan, Warszawa 2012, s. 59-60. Podobnie, jak się wydaje, S. Włodyka, op. cit., s. 14-16, który wskazuje, że w porządkach, w których przyjęto zasadę jedności prawa prywatnego, problematyka handlowoprawna jest włączana do kodeksów cywilnych w znacznym stopniu jedynie formalnie, bez utraty swojej odrębności. Zob. też A. Szumański, S. Włodyka, [w:] System Prawa Handlowego, t. 2A. Prawo spółek handlowych, red. A. Szumański, Warszawa 2019, s. 7, którzy rozwiązanie przyjęte w Polsce określają mianem kodyfikacji prawa spółek o charakterze zewnętrznym. 
Istnienia norm prawa handlowego, rozsianych w samym kodeksie cywilnym lub poza nim, nie sposób kwestionować. Nikt tego zresztą nie robi, co jednak dowodzi tego, że mówiąc o monizmie prawa prywatnego, trwamy w istocie w pewnej systemowej niekonsekwencji. Co ciekawe, stan ten sam w sobie nie budzi kontrowersji tak długo, jak nie towarzyszy mu propozycja odstąpienia od monistycznej koncepcji prawa prywatnego. Zaliczanie norm prawa handlowego do prawa cywilnego wydaje się więc obecnie zabiegiem o znaczeniu jedynie porządkującym, który z jednej strony ma uzasadniać przyjętą systematykę norm polskiego prawa prywatnego, z drugiej zaś umożliwiać oparcie stosunków prawnohandlowych na całej cywilistycznej bazie normatywnej. W rozwiązaniu tym, prima facie prostym i funkcjonalnym, brakuje jednak uporządkowanego całościowego spojrzenia na stosunki handlowe, konsekwentnej i spójnej koncepcji instytucji przedsiębiorcy (w tym w wymiarze ustrojowym), stosunków prawnych z jego udziałem i zasad ogólnych, które by nimi rządziły. Brakuje zatem przede wszystkim solidnego prawnego fundamentu obrotu handlowego 25 .

Pytanie, które w tym kontekście można więc zadać, dotyczy w mniejszym stopniu tego, czy trwać przy monizmie albo powrócić do dualizmu prawa prywatnego, ale bardziej tego, czy nie nadszedł właśnie dogodny i właściwy czas, aby rozpocząć prace nad usystematyzowaniem regulacji prawnohandlowej, czy to w ramach nowego kodeksu handlowego, czy to w ramach struktury kodeksu cywilnego, przede wszystkim jednak przy dokonaniu jej gruntownego przeglądu i korekt pożądanych z punktu widzenia uczestników obrotu. Nie ulega przy tym wątpliwości, że dalsze rozwarstwianie kodeksu cywilnego regulacjami prawnohandlowymi — co jest właściwe dotychczasowemu modelowi - jest nieuniknione. To z kolei będzie czynić ten kodeks coraz mniej przejrzystym, a w konsekwencji coraz mniej funkcjonalnym, dla adresatów zaś (wszystkich, nie tylko przedsiębiorców) zawartych w nim norm — coraz trudniejszym w stosowaniu. Problem ma zatem znaczenie nie tylko teoretyczne, lecz przede wszystkim praktyczne.

Paradoksalnie, mówiąc dziś o przyszłości prawa handlowego, należy spojrzeć za siebie i zastanowić się, czy argumenty sprzed lat trzydziestu nadal pozostają aktualne. O ile bowiem w latach dziewięćdziesiątych XX wieku dystansowanie się od koncepcji odrębnej regulacji dla „stanu kupieckiego” było poniekąd zrozumiałe (kilkudziesięcioletni okres funkcjonowania poza ramami gospodarki rynkowej, dynamika zmian gospodarczych i politycznych oraz wymuszony nimi pośpiech działań prawodawczych, a także górowanie głosu klasycznej cywilistyki nad odradzającą się dopiero nauką prawa handlowego), o tyle dalsze trwanie przy takim

25 Por. jednak W. Katner, Zasada jedności prawa cywilnego a wspótczesny zakres podmiotowoprzedmiotowy stosunków handlowych, [w:] Prawo handlowe. Między teoria, praktyką a orzecznictwem. Ksiegga jubileuszowa dedykowana profesorowi Januszowi A. Strzępce, red. P. Pinior, Warszawa 2019, s. 45 n., który opowiada się przeciwko wprowadzeniu części ogólnej prawa handlowego, postulując utrzymanie (,pielęgnację”) jedności prawa cywilnego, mającej wynikać „ze wspólnoty stosunków społeczno-gospodarczych, określanych mianem cywilnoprawnych”. 
założeniu staje się coraz trudniejsze. Postępująca profesjonalizacja i specjalizacja obrotu handlowego skutkuje stałym rozbudowywaniem odnoszącej się do niego regulacji prawnej, również tej o proweniencji unijnej, przy jednoczesnym pogłębianiu się jej skomplikowania. Utrzymywanie fikcji jedności prawa prywatnego w jej aktualnym kształcie zmusza i będzie zmuszać prawodawcę do doraźnego, punktowego „łatania” kodeksu cywilnego i aktów okołokodeksowych, sprzyjając rozbijaniu wewnętrznej spójności tego kodeksu (por. na przykład regulację rękojmi, w której przeplatają się przepisy dotyczące obrotu powszechnego, konsumenckiego i dwustronnie profesjonalnego, zwłaszcza w brzmieniu nadanym nowelizacją, która ma wejść w życie 1 stycznia 2021 roku $^{26}$ ) lub zjawisku dekodyfikacji (na przykład ustawa o przeciwdziałaniu nadmiernym opóźnieniom w transakcjach handlowych ${ }^{27}$ ). Wciąż aktualny — i to mimo upływu blisko trzech dekad — pozostaje stan scharakteryzowany przez J. Frąckowiaka:

ustawodawca, mając gotową regulację tak znacznej części problematyki dotyczącej podmiotów prowadzących działalność gospodarczą [tj. utrzymane w mocy przepisy kodeksu handlowego i normy prawa handlowego pomieszczone w kodeksie cywilnym — przyp. K.K.], poczuł się w dużej mierze zwolniony z potrzeby całościowego spojrzenia na tę kwestię bądź w kodeksie cywilnym, bądź w innym akcie prawnym ${ }^{28}$.

Niezmiennie brakuje kompleksowego uregulowania obrotu gospodarczego czy nawet samej tylko jego części ogólnej; zmieniło się jedynie usprawiedliwienie prawodawcy, który przed pytaniami o dalszy kierunek rozwoju prawa handlowego może się dziś ukryć za fasadowym twierdzeniem o zasadzie jedności

26 Zob. art. 1 pkt 2 ustawy z dnia 31 lipca 2019 roku o zmianie niektórych ustaw w celu ograniczenia obciążeń regulacyjnych (Dz.U. z 2019 r. poz. 1495), który pierwotnie miał wejść w życie 1 czerwca 2020 roku. Data ta została przesunięta na 1 stycznia 2021 zgodnie z art. 62 pkt 2 ustawy z dnia 31 marca 2020 roku o zmianie ustawy o szczególnych rozwiązaniach związanych z zapobieganiem, przeciwdziałaniem i zwalczaniem COVID-19, innych chorób zakaźnych oraz wywołanych nimi sytuacji kryzysowych oraz niektórych innych ustaw (Dz.U. z 2020 r., poz. 568). Dyskusyjna jest przy tym już sama formuła wprowadzana na mocy tej nowelizacji — ,osoba fizyczna zawierająca umowę bezpośrednio związaną z jej działalnością gospodarczą, gdy z treści tej umowy wynika, że nie posiada ona dla tej osoby charakteru zawodowego, wynikającego w szczególności z przedmiotu wykonywanej przez nią działalności gospodarczej, udostępnionego na podstawie przepisów o Centralnej Ewidencji i Informacji o Działalności Gospodarczej”. Niezależnie od wątpliwości natury teoretycznej co do logiki tego sformułowania należy się spodziewać, że będzie ona przedmiotem sporów w praktyce obrotu i przyczyną rozbieżności orzecznictwa.

27 Ustawa z dnia 8 marca 2013 roku o przeciwdziałaniu nadmiernym opóźnieniom w transakcjach handlowych, Dz.U. z 2019 r. poz. 118.

28 J. Frąckowiak, O konieczności..., s. 8. Ocenę tę można uzupełnić przytoczeniem deklaracji prawodawcy z okresu prac nad kodeksem spółek handlowych, zgodnie z którą jego uchwaleniu miała towarzyszyć reforma kodeksu cywilnego zmierzająca „w kierunku odpowiedniej rozbudowy części ogólnej kodeksu, uwzględniającej w szerszym niż dotychczas stopniu problematykę podmiotów prawa cywilnego i organów rozmaitych typów osób prawnych, co powinno doprowadzić do większej harmonii między przepisami nowego prawa spółek handlowych i k.c.”, uzasadnienie projektu ustawy — Kodeks spółek handlowych, pkt I 4. 
prawa prywatnego i autonomii kodeksu spółek handlowych. Poza ewentualnym wyciszeniem wyrzutów sumienia ustawodawcy nie zmieniają one jednak ciągłego tkwienia przez niego, a przede wszystkim przez uczestników obrotu w coraz bardziej uwierającym stanie zawieszenia.

W dyskusji poprzedzającej uchwalenie kodeksu spółek handlowych jednym $\mathrm{z}$ argumentów podnoszonych przeciwko opracowywaniu nowego kodeksu handlowego, a w konsekwencji przeciwko powrotowi do tradycyjnie rozumianego dualizmu prawa prywatnego, był aspekt czasowy oraz dyktowana szybkością przeobrażeń gospodarczych i potrzebą harmonizacji z prawem europejskim konieczność sprawnego przeprowadzenia prac legislacyjnych nad przepisami prawa spółek $^{29}$. Rozdział żywiołowej transformacji polskiej przedsiębiorczości jest już jednak zamknięty; również sami przedsiębiorcy okrzepli w roli uczestników gry rynkowej, wykazując coraz większą świadomość prawną oraz zdolność identyfikowania i artykułowania swoich potrzeb. Wydaje się więc, że czas stabilizacji i zrównoważonego rozwoju gospodarczego sprzyja podjęciu trudu opracowania przemyślanej, całościowej, spójnej i możliwie elastycznej regulacji obrotu handlowego, która odpowiadałaby na jego aktualne i spodziewane przyszłe potrzeby.

Jakkolwiek kwestią o znaczeniu przede wszystkim technicznym jest, czy owa kompleksowa regulacja przybrałaby formę odrębnego aktu prawnego, czy zostałaby w uporządkowany sposób włączona do kodeksu cywilnego (wymuszając modyfikację tradycyjnego układu pandektowego), w świetle oddalającej się wizji opracowania nowego kodeksu cywilnego na uwagę zasługuje opcja formalnego wyodrębnienia prawa handlowego. Rozwiązanie to sprzyjałoby utrzymaniu ładu legislacyjnego i pozwoliło uniknąć tworzenia nazbyt rozbudowanych aktów prawnych. Trzeba jednak odpowiedzieć na pytanie, w jakim stopniu — w razie wyłączenia materii prawa handlowego do osobnego kodeksu — możliwe jest „uwolnienie się" od kodeksu cywilnego. Jest to w istocie pytanie o treść i zakres regulacji nowego kodeksu handlowego. Chodzi tu przede wszystkim o ogólne przepisy kodeksu cywilnego, które dziś służą obrotowi powszechnemu i gospodarczemu. Kompleksowe unormowanie stosunków prawnohandlowych wymagałoby więc przesądzenia, czy zostaną one powielone w kodyfikacji prawa handlowego lub do niego przeniesione $\mathrm{z}$ kodeksu cywilnego (gdy dany przepis dotyczy wyłącznie stosunków handlowych — na przykład art. $66^{2}, 68^{1}, 68^{2}$ k.c.), czy też ponownie zastosowano by odesłanie do podlegających odpowiedniemu stosowaniu przepisów kodeksu cywilnego ${ }^{30}$, co jednak pomniejszałoby sens całego założenia. $\mathrm{Na}$

${ }^{29}$ Zob. uzasadnienie projektu ustawy - Kodeks spółek handlowych, pkt I 3; S. Sołtysiński, Kodeks spótek handlowych..., s. 8; M. Tarska, Problemy polskiego prawa handlowego okresu transformacji, „Studia Prawnicze” 1999, nr 3, s. 63.

${ }^{30}$ Mechanizm odesłania do przepisów prawa cywilnego został zastosowany w kodeksie handlowym — rozporządzenie Prezydenta Rzeczypospolitej z dnia 27 czerwca 1934 roku — Kodeks handlowy (Dz.U. Nr 57, poz. 502). Zgodnie z jego art. 2 znajdowały one zastosowanie do stosunków handlowych dopiero w braku przepisów kodeksu handlowego, ustaw szczególnych i powszechne- 
problem ten wskazano zresztą jeszcze przed uchwaleniem kodeksu spółek handlowych (choć - co warto zauważyć — bynajmniej nie po to, żeby odwodzić od zerwania z jednością prawa prywatnego) ${ }^{31}$. Rozstrzygnięcie tej kwestii byłoby jednym z najpoważniejszych, przynajmniej na płaszczyźnie formalnej, wyzwań, $\mathrm{z}$ jakimi trzeba by zmierzyć się $\mathrm{w}$ ramach powrotu do dualistycznej koncepcji prawa prywatnego.

IV. Kodeks spółek handlowych — bo to o nim przede wszystkim tu mowa — będzie oczywiście funkcjonować, i to bez poważnych zakłóceń, niezależnie od tego, czy ustawodawca zdecyduje się na przemodelowanie koncepcji prawa prywatnego (chociaż można sobie wyobrazić, że uchylenie potrzeby posiłkowego i niekiedy problematycznego stosowania kodeksu cywilnego do stosunków prawnospółkowych mogłoby przynieść pozytywne skutki).

Niemniej jednak na tle prowadzonych rozważań kodeks spółek handlowych ze swoją choćby nieabsolutną autonomią, która w pierwotnym założeniu miała utrzymywać go w ryzach prawa cywilnego, jawi się jako przyczółek dualizmu prawa prywatnego i dowód na to, że - mówiąc nieco przekornie — poza kodeksem cywilnym również istnieje życie. W tym sensie może on stanowić zachętę do dyskusji nad tym, czy, w jaki sposób i w jakim stopniu nowa regulacja prawa handlowego powinna zostać $\mathrm{z}$ tego ostatniego wyodrębniona, według jakiego kryterium wyróżniona i w jakim zakresie poprawiona lub uzupełniona.

\section{THE AUTONOMY OF THE COMMERCIAL COMPANIES CODE - BETWEEN UNITY AND DUALITY OF PRIVATE LAW}

\section{Summary}

This study concerns the unity of private law and the idea of returning to its dualistic concept. The article's reasoning is based on the perspective of the Commercial Companies Code which, despite the normatively sanctioned monistic approach, can be considered as a specific regulation due to a far-reaching autonomy to traditional civil law as well as encouragement to discuss the return to a dual regulation of private law. Moreover, the current form of the provisions dedicated to commercial relations in the Civil code justifies the conclusion that we already have a regulatory dualism and

go w państwie prawa zwyczajowego. Za sprawą szerszego wyliczenia źródeł prawa dzielących kodeks handlowy od przepisów prawa cywilnego nieco inaczej więc rozłożony był akcent w porównaniu chociażby ze współczesną regulacją art. 2 k.s.h. (zob. M. Honzatko, [w:] T. Dziurzyński, Z. Fenichel, M. Honzatko, Kodeks handlowy. Komentarz, t. 1, Lódź 1992, s. 6-7; M. Allerhand, Kodeks handlowy. Komentarz, Lwów 1935, s. 2; M. Pazdan, op. cit., s. 28-29). Praktyczne znaczenie owego odesłania do prawa cywilnego osłabiało też w pewnym stopniu to, że ówczesnie brakowało kompletnej kodyfikacji cywilnej. Por. A. Kidyba, Komentarz aktualizowany..., art. 2 uw. 2, który wskazuje, że stan wyznaczony art. 2 k.s.h. jest w istocie podobny to tego pod rządami art. 1 k.h.

31 Zob. S. Włodyka, op. cit., s. 20-21, który dostrzegał ryzyko powtarzania w kodeksie handlowym regulacji o charakterze ogólnym albo konieczność odsyłania do kodeksu cywilnego, co czyniłoby powrót do dualizmu pozornym. 
that the notion of "unity" can be reasonably mentioned in the context of codification unity only. This circumstance, together with the progressive specialisation of trade and favourable socio-economic conditions, are inclined to review, reorganise, and complete the normative, essential regulation of this sphere either in the Civil code or in a new commercial code.

Keywords: commercial law, civil law, private law, company law, monism of private law, duality of private law, unity of private law, Commercial Companies Code, civil code, autonomy of company law

\section{BIBLIOGRAFIA}

Allerhand M., Kodeks handlowy. Komentarz, Lwów 1935.

Bieniak J. et al., Kodeks spółek handlowych. Komentarz, Warszawa 2020.

Bilewska K., Warzecha M., Dopuszczalność stosowania art. 58 \& 3 k.c. do uchwat zgromadzeń spólek kapitałowych — polemika, PPH 2010, nr 7.

Brol J. et al., Kodeks spótek handlowych. Komentarz, Warszawa 2001.

Całus A., Miejsce instytucji prawa handlowego w procesie komercjalizacji prawa cywilnego. Uwagi w zwiazku z pracami nad nowym kodeksem cywilnym, [w:] Instytucje prawa handlowego w przyszłym kodeksie cywilnym, red. T. Mróz, M. Stec, Warszawa 2012.

Całus A., Problematyka handlowa w reformie kodeksu cywilnego (I), „Przegląd Ustawodawstwa Gospodarczego" 1990, nr 8-9.

Dziurzyński T., Fenichel Z., Honzatko M., Kodeks handlowy. Komentarz, t. 1, Łódź 1992.

Frąckowiak J., Instytucje prawa handlowego w kodeksie cywilnym, „Rejent” 2003, nr 6.

Frąckowiak J., O konieczności dalszych zmian prawa cywilnego szczególnie w odniesieniu do podmiotów i umów w obrocie gospodarczym, PPH 1999, nr 3.

Frąckowiak J., Ustawodawstwo dotyczace przedsiębiorców pod rządami zasady jedności prawa cywilnego, PPH 2000, nr 11.

Gutowski M., Dopuszczalność stosowania art. 58 \& 3 k.c. do podlegajacych uchyleniu uchwat zgromadzenia wspólników lub walnego zgromadzenia spótek kapitałowych, PPH 2009, nr 12.

Jacyszyn J., Projekt ustawy - Prawo spótek handlowych (ogólna charakterystyka), „Rejent” 1999, $\mathrm{nr} 1$.

Katner W., Zasada jedności prawa cywilnego a współczesny zakres podmiotowo-przedmiotowy stosunków handlowych, [w:] Prawo handlowe. Między teoria, praktyka a orzecznictwem. Księga jubileuszowa dedykowana profesorowi Januszowi A. Strzepce, red. P. Pinior, Warszawa 2019.

Kidyba A., Komentarz aktualizowany do art. 1-300 Kodeksu spótek handlowych, Warszawa 2020.

Kidyba A., Prawo handlowe, Warszawa 2019.

Kodeks cywilny. Komentarz, red. J. Ciszewski, P. Nazaruk, Warszawa 2019.

Kodeks spółek handlowych. Komentarz, red. W. Pyzioł, Warszawa 2008.

Kodeks spółek handlowych. Komentarz, red. J. Strzępka, E. Zielińska, Warszawa 2015.

Kodeks spótek handlowych. Komentarz, red. Z. Jara, Warszawa 2020.

Kodeks spótek handlowych. Komentarz. Tytut I. Przepisy ogólne. Tytut II. Spółki osobowe, red. T. Siemiątkowski, R. Potrzeszcz, Warszawa 2011.

Kruczalak K., Prawo handlowe. Zarys wyktadu, Warszawa 1997.

Kurnicki T., Stosowanie przepisów o wadach oświadczeń woli w prawie spótek (cz. I), „Prawo Spółek" 2006, nr 6.

Okolski J., Opalski W., Znaczenie prawa handlowego w świetle koncepcji jedności prawa cywilnego, PPH 1992, nr 1.

Paluch M., Kierunki reformy prawa spółek handlowych, MoP 1998, nr 8.

Pazdan M., Kodeks spótek handlowych a kodeks cywilny, PiP 2001, nr 2. 
Radwański Z., Koncepcja kodyfikacji prawa cywilnego, [w:] Księga pamiątkowa. I Kongres Notariuszy Rzeczypospolitej Polskiej, red. A. Oleszko, R. Sztyk, Poznań-Kluczbork 1993.

Rodzynkiewicz M., Kodeks spółek handlowych. Komentarz, Warszawa 2018.

Skąpski J., Kodeks cywilny z 1964 r. Blaski i cienie kodyfikacji oraz jej perspektywy, KPP 1992, nr $1-4$.

Skąpski J., O stanie i potrzebach prawa cywilnego — uwag kilka, „Przegląd Sądowy” 1992, nr 7-8.

Sołtysiński S., Kodeks spótek handlowych. (Podstawowe założenia), PiP 2000, nr 11.

Sołtysiński S., Przepisy ogólne kodeksu spółek handlowych. (Wybrane zagadnienia), PiP 2001, nr 7.

Sołtysiński S., Spóźniona reforma prawa spółek handlowych, PPH 1999, nr 5.

Sołtysiński S., Szajkowski A., Szwaja J., Kodeks handlowy. Komentarz, t. 1, Warszawa 1994.

Sołtysiński S., Szajkowski A., Szwaja J., Założenia reformy prawa spółek handlowych (z prac Komisji Kodyfikacyjnej Prawa Cywilnego), „Prawo Spółek” 1997, nr 6.

Strzępka J., Zielińska E., Pinior P., Popiołek W., Kodeks spółek handlowych. Komentarz, Warszawa 2015.

System Prawa Handlowego, t. 2A. Prawo spółek handlowych, red. A. Szumański, Warszawa 2019. System Prawa Prywatnego, t. 1. Prawo cywilne - część ogólna, red. M. Safjan, Warszawa 2012.

System Prawa Prywatnego, t. 16. Prawo spółek osobowych, red. A. Szajkowski, Warszawa 2016.

Szwaja J., Nowy kodeks spółek handlowych, cz. 1-2, „Prawo Spółek” 2001, nr 1.

Tarska M., Problemy polskiego prawa handlowego okresu transformacji, „Studia Prawnicze” 1999, nr 3.

Wilejczyk M., Stosowanie przepisów kodeksu cywilnego do wadliwych uchwał zgromadzeń wspólników spółek kapitałowych, PPH 2012, nr 4.

Włodyka S., O sposobach normatywnej regulacji prawa handlowego, PiP 1999, nr 9. 